Original Articles

\title{
Association among nursing diagnoses, demographic variables, and clinical characteristics of patients with high blood pressure*
}

\author{
Associação entre diagnósticos de enfermagem e variáveis sociais/clinicas em pacientes hipertensos \\ Asociación entre diagnósticos de enfermería y variables sociales/clinicas en pacientes hipertensos
Francisca de Fátima Vasconcelos ${ }^{1}$,Thelma Leite de Araújo ${ }^{2}$, Thereza Maria Magalhães Moreira ${ }^{3}$, Marcos Venícios de Oliveira Lopes ${ }^{4}$

\begin{abstract}
Objectives: To analyze the association among diagnoses, demographic variables, and clinical characteristics of patients with high blood pressure. Methods: The data were collected in 67 patients from a primary care unit in Fortaleza, Brazil. The NANDA Taxonomy was used to determine the nursing diagnoses. Data analysis consisted of Fisher's exact test, Chi-square test, and likelihood ratio test. Results: Fifty four nursing diagnoses were identified; fifteen were above the $75^{\text {th }}$ percentile. Ineffective individual therapeutic regimen management and number of medication, sleep pattern disturbance and marital status, activity intolerance and education, activity intolerance and time of diagnoses, sexual dysfunction and gender, sexual dysfunction and education, risk for falls and age, marital status and time of diagnoses, chronic pain and marital status all had significant association coefficients. Conclusion: Some demographic characteristics were associated with nursing diagnoses.
\end{abstract}

Keywords: Hypertension; Nursing diagnosis; Nursing; Socioeconomic factors

\section{RESUMO}

Objetivo: Analisar a associação estatística entre diagnósticos e características sociais / clínicas de pacientes hipertensos. Métodos: Os dados foram coletados numa unidade básica de saúde de Fortaleza-Ce com 67 pacientes. A identificação dos diagnósticos foi procedida segundo a taxonomia da NANDA. Para análise dos dados utilizou-se testes de Fisher, Qui-Quadrado de Pearson e Razão de Verossimilhança. Resultados: Encontrou-se 54 diagnósticos de enfermagem e 15 acima do percentil 75. Verificou-se associação estatística entre: Controle eficaz do regime terapêutico e número de medicamentos; Padrão de sono perturbado e estado civil; Intolerância à atividade e escolaridade e anos de diagnóstico; Disfunção sexual e sexo e escolaridade; Risco para quedas e idade, estado civil e tempo de diagnóstico da doença; Dor crônica e estado civil. Conclusão: Algumas características demográficas estão associadas à ocorrência de diagnósticos de enfermagem.

Descritores: Hipertensão; Diagnóstico de enfermagem; Enfermagem; Fatores socioeconômicos

\section{RESUMEN}

Objetivo: Analizar la asociación estadística entre diagnósticos y características sociales / clínicas de pacientes hipertensos. Métodos: Los datos fueron recolectados en una unidad básica de salud de Fortaleza-Ceará con 67 pacientes. La identificación de los diagnósticos se llevó a cabo según la taxonomía de la NANDA. Para el análisis de los datos se utilizó test de Fisher, Chi-Cuadrado de Pearson y Razón de Verosemejanza. Resultados: Se encontró 54 diagnósticos de enfermería y 15 sobre el percentil 75. Se verificó asociación estadística entre: Control eficaz del régimen terapéutico y número de medicamentos; Patrón de sueño perturbado y estado civil; Intolerancia a la actividad y escolaridad y años de diagnóstico; Disfunción sexual y sexo y escolaridad; Riesgo para caídas y edad, estado civil y tiempo de diagnóstico de la enfermedad; Dolor crónico y estado civil. Conclusión: Algunas características demográficas están asociadas a la ocurrencia de diagnósticos de enfermería.

Descriptores: Hipertensión; Diagnóstico de enfermería; Enfermería; Factores socioeconómicos

\footnotetext{
"This article is part of the Masters Thesis "Nursing diagnoses in patients with high blood pressure: a study in a specific population", presented in the Nursing Graduation Program at the Ceara Federal University (UFC) at College of Nursing, Fortaleza (CE), Brazil; which is part of the Project for Integrated Cardiovascular Health Actions $N^{\circ} 500639 / 2003-5$ and receives funding (scholarship) from FUNCAP.

${ }^{1}$ MNS by the Ceará Federal University-UFC - Fortaleza (CE) - Brazil.

${ }^{2}$ DNS, Associate Professor at the Ceará Federal University - UFC - Fortaleza (CE) - Brazil.

DNS, Associate Professor at the Ceará Federal University - UFC - Fortaleza (CE) - Brazil.

${ }^{4}$ DNS, Associate Professor at the Ceará Federal University - UFC - Fortaleza (CE) - Brazil.
} 


\section{INTRODUCTION}

Nursing has sought to develop practices founded on scientific methods, adopting health care systematization as the form of work, which enables individualized, ordered, and result-oriented health care. Stages concerning data collection, diagnosis, planning, prescribing interventions, and evaluating the obtained results, have been the object of several studies performed with the purpose of improving the art of nursing and increasing scientific knowledge to provide clients with more appropriate health care.

Nursing diagnosis functions as the foundation for formulating interventions, and has, alone, congregated an array of studies performed with specific groups having particular common conditions, like age range ${ }^{(1)}$, diagnosis $^{(2)}$, or even life condition ${ }^{(3)}$. Some of these studies have pointed at a possible association between certain diagnoses and a specific situation or population. This suggests that the formulation of one diagnosis could imply the occurrence of others. Some authors ${ }^{(4)}$ have studied people with oncological pain and found that some diagnoses have a certain occurrence pattern. In this view, $\mathrm{Cruz}^{(5)}$ suggested that chronic pain could be a syndrome and not merely a diagnosis category. The referred study considered that syndromes would be groups of manifestations, and results pointed at a possible chronic pain syndrome, comprised by the following diagnoses: disturbed sleep pattern, knowledge deficit, anxiety, fear, activity intolerance, and impaired physical mobility. More recently, Silva, Lopes, and Araujo ${ }^{(6)}$ studied children with congenital heart disease and found a strongly significant statistical association between the nursing diagnosis: inefficient breathing pattern, inefficient airway clearance, and hyperthermia. This also suggests the study of a possible syndrome.

Further studies should be performed to search for associations between different nursing diagnoses, comprising syndromes or not, and between nursing diagnoses and specific characteristics of the studied group. This thought is founded on the benefits that would result from these studies, for instance: broadening the view over clients' needs, since the fact that identifying a diagnosis could be the clue to other diagnoses; deepening the knowledge about risk factors as well as about the associated factors, since combined diagnoses could be considered a risk factor or be related with the onset of other diagnoses; and, finally, contributing to the construction of a more consistent foundation to elaborate effective interventions that would yield significant results.

Hence, the purpose of this study is to elaborate nursing diagnoses for hypertensive individuals, aiming to associate them with the social and cultural characteristics of the studied population.

\section{METHODS}

This is a quantitative, cross-sectional, descriptive study. The study population consisted of hypertensive patients followed at a basic health unit in the city of Fortaleza, Ceara State, Brazil, who were registered in the HIPERDIA Program. This program was developed by the Health Ministry with the purpose to provide a profile of patients with hypertension and/or diabetes, and to learn which drugs they took. The inclusion criteria were: being registered in the HIPERDIA program before February 2004 and participate in a specific area of the Family Health Program, in which one of the researchers would perform nursing assistance; have systemic hypertension associated or not to other cardiovascular conditions; have the necessary physical and mental conditions to answer interview questions; have completed at least one year of diagnosis and disease treatment; and voluntarily agree to participate in the study. Of the 374 registered individuals, 67 patients met the established requirements, thus composing the study sample.

Data were collected at the patients' homes, from March to July 2004, during a nursing visit. The instrument used for data collection and diagnosis identification was based on the North American Nursing Diagnosis Association (NANDA) Taxonomy II ${ }^{(7)}$. The studied social and clinical characteristics were: age, gender, marital status, education, religion, occupation, family income, as well as time of disease diagnosis, number of drugs, and body mass index.

Patients were considered single if they reported being single, divorced, or widowed; and were considered married if they stated they were married or living together. Patients' age was divided into four ranges; the youngest patient was 39 years old, and the oldest was 89. Education was classified in three levels (illiterate, incomplete primary education, or complete secondary education). Religion was classified in two categories (catholic and other religions). Regarding occupation, the categories were: retired, housekeeper, and others (all other professions). Three categories concerned income (below one minimum salary, between one and two minimum salaries, and above two minimum salaries). The time of diagnosis was presented in three ranges (one to five years, six to ten years, over eleven years), and body mass index was classified in three levels (normal, overweight, and obese). The number of drugs was divided in the categories: one drug and two or more drugs.

To analyze the associations between diagnoses and variables, the non-parametric Pearson's Chi-Square, Fischer's, and Likelihood-ratio tests were used, based on their respective presuppositions ${ }^{(8)}$. Significance was established at $5 \%(\mathrm{p}<.05)$.

The study was approved by the Institutional Review Board, and complies with the ethical aspects of research 
with human beings ${ }^{(9)}$.

\section{RESULTS}

Sixty-seven patients were interviewed. Most participants were women $(73.1 \%)$, within the age range of 50 to 69 years $(67.2 \%), 70.8 \%$ were married, and $82.1 \%$ were catholic. Regarding education, $28.8 \%$ were illiterate, and $57.6 \%$ had incomplete primary education. As to occupation, $65.5 \%$ were housekeepers, and $20.0 \%$ were retired. The prevalent family income range was one to four minimum salaries (70.4\%), and $44.8 \%$ had time of diagnosis of one to five years. Regarding the participants' body mass index (BMI), it was identified that $43.5 \%$ were overweight and $37.1 \%$ were obese type 1. In average, patients took 1.6 drugs ( \pm .55$)$. As to the doses, $19 \%$ took their medication once a day; $50 \%$ twice a day; and 31\% took three daily doses. Regarding the number of antihypertensive drugs, $43.3 \%$ took only one drug, 53.7\% took two drugs, and 3\% took three drugs.

The data obtained in this study permitted to formulate 54 nursing diagnosis, distributed in the several domain classes of the taxonomy used. There was an average of seven diagnoses per patient, and most had diagnoses in more than one domain. Fifteen diagnoses $(26.7 \%)$ had frequency above the $75^{\text {th }}$ percentile and were, therefore, analyzed.

Diagnoses above the $75^{\text {th }}$ percentile were distributed among 10 of the 12 studies domains. Domains that did not include diagnoses above the $75^{\text {th }}$ percentile were: Selfperception, and Coping/Stress Tolerance.

The diagnosis "effective therapeutic regimen management" showed a statistically significant association with the number of drugs used by patients (Fisher/ $\mathrm{p}=0.016$ ). That is, those using only one drug were 5.241 (IC 95\% $=1.20-22.84$ ) times more likely to have effective therapeutic regimen management, compared to those taking two or more drugs.

"Disturbed sleep pattern" was associated with the variable "marital status" $\left(\mathrm{x}^{2}=8.86, \mathrm{p}=0.002\right)$, which means that $61.1 \%$ of the single patients $(11 / 18)$ had disturbed sleep patterns, whereas the percentage for married patients was $19.1 \%$. Moreover, single patients' chance of having disturbed sleep pattern was 6.635 (IC $95 \%=1.74-26.44$ ) times higher than for married patients. That is, 5.635 times more.

There was an association between "activity intolerance" and years of hypertension diagnosis" (Fisher/ $\mathrm{p}=0.022$ ), showing that patients with over 11 years of diagnosis were 10.66 (IC 95\%= $1.05-259.83$ ) times more likely for the diagnosis than patient in the range "6 to 10 years". Regarding education ( $\mathrm{p}=0.008)$, illiterate patients were 5.940 (IC $95 \%=1.38-27.12)$ times more likely to present "activity intolerance" than those with incomplete primary education.

It was found that the diagnosis "sexual dysfunction" was associated with the variables "age" $\left(\mathrm{x}^{2}=6.85\right.$, $\mathrm{p}=0.008)$ and "education" $(\mathrm{p}=0.012)$. Patients with complete primary or secondary education were 10.67 (IC $95 \%=1.27-114.72$ ) times more likely to develop sexual dysfunction than illiterate patients. As to the variable "gender", male patients were 4.352 (IC 95\% $=1.22-$ 16.03) times more likely to develop sexual dysfunction compared to females.

The nursing diagnosis "risk for falls" was associated with the variables: age, marital status, and time of diagnosis. As to age, patients between 61 and 70 years of age had 7.80 (IC 95\%= $1.17-60.77 ; \mathrm{x}^{2}=6.45$; $\mathrm{p}=0.011)$ more chances, and those between 71 and 89 years were 39 times more prone to this diagnosis, compared to patients between 39 and 50 years of age (IC 95\% $=2.76-1257.76$; Fisher $/ \mathrm{p}<0.001$ ). It is observed that aging contributes to increasing patients' chances of developing this diagnosis. Regarding marital status $\left(\mathrm{x}^{2}=6.34 ; \mathrm{p}=0.011\right)$, single patients were 5.217 (IC $95 \%=1.18-26.31)$ times more likely to develop this diagnosis than married patients.

It was found that the variable "time of diagnosis" has a direct relation with the diagnosis "risk for falls", that is, patients with over 11 years of diagnosis are 7.41 times more likely to have risk for falls, compared to those with 5 years of diagnosis. This agrees with the increase in age and disease complications (IC 95\% $=1.54$ $\left.-40.43 ; \mathrm{x}^{2}=8.68 ; \mathrm{p}=0.003\right)$.

An association was found between the diagnosis "chronic pain" and the variable "marital status" (Fisher/ $\mathrm{p}=0.027$ ). Single patients were 4.222 (IC $95 \%=1.13-$ 16.26) times more likely to develop chronic pain than married patients. In addition, this diagnosis had a statistically significant association with using only one drug (IC $95 \%=1.77-24.95 ; \mathrm{x}^{2}=10.97, \mathrm{p}<0.001, \mathrm{OR}=$ 6.50).

No statistically significant associations were found between the studied variables and the following nursing diagnoses: ineffective therapeutic regimen management; imbalanced nutrition: more than body requirements; constipation; impaired walking; impaired physical mobility; deficient knowledge; dysfunctional family processes: alcoholism; readiness for enhanced spiritual well-being; and impaired dentition.

\section{DISCUSSION}

It is observed that ten patients presented the diagnosis "effective therapeutic regimen management". None of these patients were obese, but $80.0 \%$ were overweight. Nevertheless, these patients were classified as having effective therapeutic regimen management considering 
the following parameters: patients' blood pressure was within normal limits; they reported being aware of the complications that weight gain could pose to their health; they reported having control over their diet. Patients also presented the defining characteristics of choosing daily activities to reach the goals of a treatment program and the wish to manage their disease treatment and prevent sequelae.

The dependence relation between this diagnosis and the number of drugs used highlights the need for early detection of the disease, considering that earlier patient assessment, diagnosis, and treatment reduces the chances of their having to use more than one drug. Studies involving hypertensive patients under drug therapy, which addressed the characteristics associated with their noncompliance with blood pressure management, showed that patients who took antihypertensive drugs more than once a day had the highest rates for not managing hypertension. The study also reported that the main intervening factors present in non-compliance were: number of doses; number of drugs; drug administration time, side effects, drug effectiveness, prolonged treatment, changes in the therapeutic regimen, and treatment discontinuity $^{(10-11)}$.

It is observed that detecting this diagnosis in hypertensive patients is important. For effective hypertension management, patients need to obtain information about their disease, risk factors, complications, drugs and their possible effects, and other health care procedures. Riccio and Silva ${ }^{(12)}$ state that this information is essential for patients to become aware about treatment compliance and develop self-care, which would result in enhanced compliance and avoid hospitalizations, including in intensive care units due to complications. This information, offered by health care professionals, should be delivered individually and according to each person's learning abilities, so as to improve compliance.

The nursing diagnosis "sexual dysfunction" was associated with males and showed higher prevalence in the age range 51 to 60 years, followed by the age range 39 to 50 years. In a study by Cunha ${ }^{(13)}$, this diagnosis was identified as being more frequent among patients in the age range 50 to 59 years. However, the author comments that it was impossible to relate this dysfunction to age range since there are reports of active sexual life in older ages. This fact agrees with the present study results, considering that, despite the prevalence, there was no indication of association between these two variables.

The diagnosis "risk for falls" was higher for females above 60 years. This is justified by the fact that, with aging, people become more prone to risk of falls and, since patients are mostly women, they often have osteomuscular problems, followed by loss of bone mass.
Studies have shown that people over 60 have a stronger chance for postural instability, changes in gait, reduced movements, changes in musculature, joint stiffening, and reduction in healthy bones. Changes in the overall body structure usually make people susceptible to falls ${ }^{(14-15)}$.

It is observed that, as of this age, people are more predisposed to osteomuscular and metabolic changes, including estrogen suppression at menopause, calcium reabsorption problems, constant bone mass demineralization, and reduced bone density, which translate into higher porosity and fragility of the boney tissue $^{(16)}$.

\section{CONCLUSION}

Taxonomy II domains should receive greater attention during nursing consultations to hypertensive patients. The following domains are highlighted: health promotion, nutrition, activity/rest, perception/cognition, sexuality, life principles, safety/protection, and comfort.

Knowledge concerning the associations found between different diagnoses and patients' social and clinical characteristics should be used when planning and implementing nursing interventions. Some associations require further studies; for instance, associations between: disturbed sleep pattern and marital status; sexual dysfunction and gender; and others.

Risk for falls was unspecific for changes in blood pressure, considering its direct relation with age. On the other hand, the association between sexual dysfunction and males could have been influenced by the type of drug used by hypertensive patients. It is important to emphasize that although there was no identified association with the number of drugs, it is acknowledged that sexual function changes are a possible side effect of specific antihypertensive drugs.

Regarding nursing practice, it was evidenced that it is important to provide health care to hypertensive individuals based on the identification of nursing diagnoses, since they guide the nursing actions to this specific population. In addition, there is a need for learning about certain social and clinical characteristics of the population, as well as about their association to particular diagnoses.

Further studies in this field are needed to enhance research concerning diagnoses that have not been addressed in the present study or did not concern this specific population.

\section{REFERENCES}

1. Silva VM. Caracterização de diagnósticos de enfermagem em crianças com cardiopatia congênita: estudo num 
hospital especializado em doenças cardiopulmonares. [tese]. Fortaleza: Universidade Federal do Ceará - Departamento de Enfermagem; 2005.

2. Cafer CR, Barros ALBL, Lucena AF, Mahl MLS, Michel JLM. Diagnósticos de enfermagem e proposta de intervenções para pacientes com lesão medular. Acta Paul Enfermagem. 2005;18(4):347-53.

3. Alves VM, Moura ZA, Palmeira ILT, Lopes MVO. Estudo do diagnóstico de enfermagem fadiga em gestantes atendidas numa unidade básica de atenção à saúde. Acta Paul Enfermagem. 2006;19(1):70-5.

4. Pimenta CAM, Cruz DALM. Câncer e dor: alterações nos padrões de resposta humana. Acta Paul Enfermagem. 1994;7(1):27-34.

5. Cruz DALM. Dor crônica: categoria diagnóstica ou síndrome? [tese]. São Paulo: Escola de Enfermagem da Universidade de São Paulo; 1998.

6. Silva VM, Lopes MVO, Araujo TL. Asociación entre diagnósticos de enfermería en niños con cardiopatías congénitas. Enferm Cardiol. 2004;11(32-33):33-7.

7. North American Nursing Diagnosis Association. Diagnósticos de enfermagem da NANDA: definições e classificação 2001-2002. Porto Alegre: Artmed; 2002. 288 p.

8. Levin J. Estatística aplicada a ciências humanas. 2a ed. São Paulo: Harbra; 1987.

9. Brasil. Ministério da Saúde. Conselho Nacional de Saúde.
Normas de pesquisa envolvendo seres humanos - Res. CNS 196/ 96. Bioética. 1996; 4(2Supl):15-25.

10. Salgado BJL, Monteiro Júnior FC, Rêgo JBB, Salgado BJL, Pereira MM, Brito LGO, Gonçalves ANR. Características associadas ao não controle da pressão arterial de pacientes hipertensos em tratamento medicamentoso. Rev Hosp Univ UFMA. 2002;3(1):13-8.

11. Sarquis LMM, Dell'Acqua MCQ, Gallani MCBJ, Moreira RM, Bocchi SCM, Tase TH, Pierin AMG. A adesão ao tratamento na hipertensão arterial: análise da produção científica. Rev Esc Enfermagem USP. 1998;32(4):335-53.

12. Riccio GMG, Silva RCG. O diagnóstico de enfermagem "déficit de conhecimento" é indicador da presença de má adesão ao tratamento por hipertensão? Cad Centro Universitário S. Camilo. 2001;7(1):37-43.

13. Cunha ICKO. Diagnósticos e intervenções de enfermagem em pacientes com hipertensão arterial em acompanhamento ambulatorial. [tese]. São Paulo: Faculdade de Saúde Pública da Universidade de São Paulo; 1999.

14. Duarte YAO, Diogo MJD. Atendimento domiciliar: um enfoque gerontológico. São Paulo: Atheneu; 2000.

15. SmeltzerSC,BareBG. Brunner\&Suddarth: tratado de enfermagem médico-cirurgica. 10a ed. Rio de Janeiro: Guanabara Koogan; 2005.

16. Araújo LAO, Santana RF, Bachion MM. Mobilidade física prejudicada em idosos: fatores relacionados e características definidoras. Rev Bras Enfermagem. 2002; 55(1):19-25. 
Table 1 - Distribution of nursing diagnoses and the respective domains and classes, Fortaleza-Ceara, March/July 2004.

\begin{tabular}{|c|c|c|c|c|}
\hline Domain & Class & Diagnosis & $\mathbf{n}$ & $\%$ \\
\hline \multirow{5}{*}{ 1-Health Promotion } & \multirow{5}{*}{ 1- Health Management } & Effective therapeutic regimen management $*$ & 10 & 14.9 \\
\hline & & Ineffective therapeutic regimen management $*$ & 57 & 85.1 \\
\hline & & Ineffective family therapeutic regimen management & 6 & 9.0 \\
\hline & & Health-seeking behaviors & 2 & 3.0 \\
\hline & & Impaired home maintenance & 3 & 4.5 \\
\hline \multirow{3}{*}{ 2-Nutrition } & \multirow{3}{*}{1 - Ingestion } & Imbalanced nutrition: more than body requirements * & 29 & 43.3 \\
\hline & & Impaired swallowing & 1 & 1.5 \\
\hline & & Risk for imbalanced nutrition: more than the body requirements & 1 & 1.5 \\
\hline \multirow{3}{*}{ 3-Elimination } & 1 - Urinary Function & Stress urinary incontinence & 2 & 3.0 \\
\hline & \multirow{2}{*}{2 - Gastrointestinal Function } & Constipation $*$ & 19 & 28.4 \\
\hline & & Risk for constipation & 1 & 1.5 \\
\hline \multirow{10}{*}{$4-$ Activity/Rest } & \multirow[t]{4}{*}{$1-$ Sleep/Rest } & Disturbed sleep pattern * & 20 & 29.9 \\
\hline & & Impaired walking $*$ & 12 & 17.9 \\
\hline & & Impaired physical mobility* & 10 & 14.9 \\
\hline & & Deficient diversional activity & 9 & 13.4 \\
\hline & \multirow[t]{4}{*}{2 - Activity/Exercise } & Feeding self-care deficit & 1 & 1.5 \\
\hline & & Dressing/grooming self-care deficit & 3 & 4.5 \\
\hline & & Bathing/hygiene self-care deficit & 2 & 3.0 \\
\hline & & Toileting self-care deficit & 1 & 1.5 \\
\hline & \multirow{2}{*}{$\begin{array}{l}\text { 4-Cardiovascular/Pulmonary } \\
\text { responses }\end{array}$} & Activity intolerance* & 15 & 22.4 \\
\hline & & Ineffective tissue perfusion & 1 & 1.5 \\
\hline \multirow{2}{*}{$\begin{array}{l}5 \text { - Perception } \\
\text { / Cognition } \\
\end{array}$} & \multirow{2}{*}{$\begin{array}{l}1 \text { - Sensation/Perception } \\
2 \text { - Cognition }\end{array}$} & Disturbed sensory perception & 7 & 10.4 \\
\hline & & Deficient knowledge $*$ & 14 & 20.9 \\
\hline \multirow{6}{*}{6 - Self-perception } & \multirow{3}{*}{$1-$ Self-concept } & Hopelessness & 4 & 6.0 \\
\hline & & Powerlessness & 3 & 4.5 \\
\hline & & Risk for loneliness & 1 & 1.5 \\
\hline & \multirow{2}{*}{2 - Self-esteem } & Situational low self-esteem & 4 & 6.0 \\
\hline & & Chronic low self-esteem & 3 & 4.5 \\
\hline & 3 - Body Image & Disturbed body image & 1 & 1.5 \\
\hline \multirow{5}{*}{ 7-Role Relationships } & 1 - Caregiving roles & Caregiver role strain & 3 & 4.5 \\
\hline & \multirow{2}{*}{2 - Family Relationships } & Dysfunctional family processes: alcoholism* & 10 & 14.9 \\
\hline & & Interrupted family processes & 7 & 10.4 \\
\hline & \multirow{2}{*}{3 - Role performance } & Impaired social interaction & 7 & 10.4 \\
\hline & & Ineffective role performance & 1 & 1.5 \\
\hline \multirow{2}{*}{8 - Sexuality } & 1 - Sexual function & Sexual dysfunction* & 24 & 35.8 \\
\hline & 1-sexual tunction & Ineffective sexuality pattern & 7 & 10.4 \\
\hline & & Dysfunctional grieving & 6 & 9.0 \\
\hline & & Anxiety & 5 & 7.5 \\
\hline & & Compromised family coping & 4 & 6.0 \\
\hline $9-$ Coping/Stress & & Impaired adjustment & 4 & 6.0 \\
\hline Tolerance & 1-Coping responses & Chronic sorrow & 2 & 3.0 \\
\hline & & Ineffective coping & 2 & 3.0 \\
\hline & & Disables family coping & 2 & 3.0 \\
\hline & & Anticipatory grieving & 1 & 1.5 \\
\hline & $1-$ Beliefs & Readiness for enhanced spiritual well-being * & 34 & 50.7 \\
\hline 10 - Life principles & $\begin{array}{l}2-\quad \text { Value/Belief/Action } \\
\text { Congruence }\end{array}$ & Noncompliance & 2 & 3.0 \\
\hline & & Impaired dentition* & 66 & 98.5 \\
\hline & & Risk for falls $*$ & 39 & 58.2 \\
\hline 11-Safety/ & & Risk for trauma & 1 & 1.5 \\
\hline Protection & 1 - Physical Injury & Risk for aspiration & 1 & 1.5 \\
\hline & & Risk for suffocation & 1 & 1.5 \\
\hline & & Impaired skin integrity & 1 & 1.5 \\
\hline 12 - Comfort & 1 - Physical comfort & Chronic pain* & 19 & 28.4 \\
\hline $12-c 01 n+0 \pi$ & $2-$ Social comfort & Social isolation & 1 & 1.5 \\
\hline
\end{tabular}

*Nursing Diagnoses above the 75 th percentile. 
Table 2 - Distribution of nursing diagnoses above the $75^{\text {th }}$ percentile and social and clinical variables, FortalezaCeara, March/July 2004.

\begin{tabular}{|c|c|c|c|c|c|c|}
\hline$\underbrace{\text { Nursing Diagnoses }}_{\text {Variables }}$ & $\begin{array}{l}\text { Effective } \\
\text { therapeutic } \\
\text { regimen } \\
\text { management }\end{array}$ & $\begin{array}{c}\text { Disturbed } \\
\text { sleep pattern }\end{array}$ & $\begin{array}{c}\text { Activity } \\
\text { intolerance }\end{array}$ & $\begin{array}{c}\text { Sexual } \\
\text { dysfunction }\end{array}$ & Risk for falls & Chronic pain \\
\hline Age & $\begin{array}{l}x^{2}=1.05 \\
p=0.306\end{array}$ & $\begin{array}{l}\mathrm{x}^{2}=0.60 \\
\mathrm{p}=0.940\end{array}$ & $\mathrm{x}^{2}=0.46 ; \mathrm{p}=0.054$ & $\begin{array}{l}\mathrm{x}^{2}=0.05 \\
\mathrm{p}=0.212\end{array}$ & $\begin{array}{c}\mathrm{x}^{2}=6.45 ; \\
\mathrm{p}=0.011 ; \\
\text { OR }=7.80 \\
\text { IC } 95 \%=1.17 \\
-60.77\end{array}$ & $\begin{array}{l}x^{2}=0.18 \\
p=0.440\end{array}$ \\
\hline Gender & $\begin{array}{l}\mathrm{x}^{2}=0.02 \\
\mathrm{p}=0.717\end{array}$ & $\begin{array}{l}\mathrm{x}^{2}=0.28 \\
\mathrm{p}=0.598\end{array}$ & $\begin{array}{l}\mathrm{x}^{2}=0.63 \\
\mathrm{p}=1.000\end{array}$ & $\begin{array}{c}\mathrm{x}^{2}=6.85 ; \\
\mathrm{p}=0.008 ; \\
\mathrm{OR}=4.35 \\
\mathrm{IC} 95 \%=1.22- \\
16.03\end{array}$ & $\begin{array}{l}x^{2}=0.09 \\
p=0.770\end{array}$ & $\begin{array}{l}\mathrm{x}^{2}=2.54 \\
\mathrm{p}=0.111\end{array}$ \\
\hline Marital Status & $\begin{array}{l}x^{2}=0.56 \\
p=1.000\end{array}$ & $\begin{array}{c}\mathrm{x}^{2}=8.86 ; \\
\mathrm{p}=0.002 ; \\
\mathrm{OR}=6.63 \\
\mathrm{IC} 95 \%=1.74- \\
26.44\end{array}$ & $\begin{array}{l}\mathrm{x}^{2}=0.96 \\
\mathrm{p}=0.328\end{array}$ & $\begin{array}{l}x^{2}=1.52 \\
p=0.217\end{array}$ & $\begin{array}{c}\mathrm{x}^{2}=6.34 ; \\
\mathrm{p}=0.011 ; \\
\mathrm{OR}=5.21 \\
\mathrm{IC} 95 \%=1.18 \\
\quad-26.31\end{array}$ & $\begin{array}{c}\text { Fisher/ } \\
\mathrm{p}=0.027 ; \\
\mathrm{OR}=4.22 \\
\text { IC } 95 \%=1.13 \\
-16.26\end{array}$ \\
\hline Education & $\begin{array}{l}x^{2}=0.38 \\
p=0.714\end{array}$ & $\begin{array}{l}\mathrm{x}^{2}=024 \\
\mathrm{p}=0.338\end{array}$ & $\begin{array}{c}\text { Fisher } / \\
\mathrm{p}=0.008 ; \\
\mathrm{OR}=5.94 \\
\text { IC } 95 \%=1.38- \\
27.12\end{array}$ & $\begin{array}{c}\text { Fisher } / \\
\mathrm{p}=0.012 ; \\
\mathrm{OR}=10.67 \\
\text { IC } 95 \%=1.27- \\
114.72\end{array}$ & $\begin{array}{l}\mathrm{x}^{2}=0.13 \\
\mathrm{p}=0.209\end{array}$ & $\begin{array}{l}x^{2}=0.27 \\
p=0.243\end{array}$ \\
\hline Religion & $\begin{array}{l}x^{2}=0.11 \\
p=0.188\end{array}$ & $\begin{array}{l}\mathrm{x}^{2}=0.256 \\
\mathrm{p}=0.323\end{array}$ & $\mathrm{x}^{2}=0.53 ; \mathrm{p}=1.000$ & $\begin{array}{l}\mathrm{x}^{2}=0.02 \\
\mathrm{p}=0.054\end{array}$ & $\begin{array}{l}\mathrm{x}^{2}=0.96 \\
\mathrm{p}=0.327\end{array}$ & $\begin{array}{l}\mathrm{x}^{2}=0.45 \\
\mathrm{p}=0.729\end{array}$ \\
\hline Occupation & $\begin{array}{l}\mathrm{x}^{2}=0.43 \\
\mathrm{p}=0.584\end{array}$ & $\begin{array}{l}\mathrm{x}^{2}=0.49 \\
\mathrm{p}=0.458\end{array}$ & $\mathrm{x}^{2}=0.42 ; \mathrm{p}=0.150$ & $\begin{array}{l}\mathrm{x}^{2}=0.07 \\
\mathrm{p}=0.185\end{array}$ & $\begin{array}{l}\mathrm{x}^{2}=0.45 \\
\mathrm{p}=0.516\end{array}$ & $\begin{array}{l}\mathrm{x}^{2}=0.43 \\
\mathrm{p}=0.042\end{array}$ \\
\hline Income & $\begin{array}{l}\mathrm{x}^{2}=0.88 \\
\mathrm{p}=0.094\end{array}$ & $\begin{array}{l}x^{2}=1.36 \\
p=0.243\end{array}$ & $\mathrm{x}^{2}=0.15 ; \mathrm{p}=0.344$ & $\begin{array}{l}\mathrm{x}^{2}=0.29 \\
\mathrm{p}=0.590\end{array}$ & $\begin{array}{l}\mathrm{x}^{2}=0.01 \\
\mathrm{p}=0.932\end{array}$ & $\begin{array}{l}x^{2}=0.07 \\
p=0.166\end{array}$ \\
\hline Time of diagnosis & $\begin{array}{l}\mathrm{x}^{2}=0.29 \\
\mathrm{p}=0.569\end{array}$ & $\begin{array}{l}x^{2}=0.10 \\
p=0.752\end{array}$ & $\begin{array}{c}\text { Fisher } / \mathrm{p}=0.022 \\
\mathrm{OR}=10.66 \\
\text { IC } 95 \%=1.05- \\
259.83\end{array}$ & $\begin{array}{l}\mathrm{x}^{2}=0.28 \\
\mathrm{p}=0.598\end{array}$ & $\begin{array}{c}\mathrm{x}^{2}=8.68 ; \\
\mathrm{p}=0.003 ; \\
\mathrm{OR}=7.41 \\
\text { IC } 95 \%=1.54- \\
40.43\end{array}$ & $\begin{array}{l}x^{2}=0.14 \\
p=0.710\end{array}$ \\
\hline Number of drugs & $\begin{array}{c}\text { Fisher } / \mathrm{p}= \\
0.016 ; \\
\mathrm{OR}=5.24 \\
\text { IC } 95 \%=1.202 \\
-22.846\end{array}$ & $\begin{array}{l}x^{2}=3.77 \\
p=0.052\end{array}$ & $\mathrm{x}^{2}=0.94 ; \mathrm{p}=0.333$ & $\begin{array}{l}x^{2}=0.91 \\
p=0.341\end{array}$ & $\begin{array}{l}\mathrm{x}^{2}=3.31 \\
\mathrm{p}=0.068\end{array}$ & $\begin{array}{c}\mathrm{x}^{2}=10.97 ; \\
\mathrm{p}<0.001 ; \\
\mathrm{OR}=6.5 \\
\mathrm{IC} 95 \%=1.77 \\
-24.95\end{array}$ \\
\hline BMI & $\begin{array}{l}\mathrm{x}^{2}=0.44 \\
\mathrm{p}=0.003\end{array}$ & $\begin{array}{l}x^{2}=0.48 \\
p=0.714\end{array}$ & $\begin{aligned} \mathrm{x}^{2} & =1.45 ? ? \\
\mathrm{p} & =0.227\end{aligned}$ & $\begin{array}{l}\mathrm{x}^{2}=0.60 \\
\mathrm{p}=0.284\end{array}$ & $\begin{array}{l}\mathrm{x}^{2}=0.17 \\
\mathrm{p}=0.430\end{array}$ & $\begin{array}{c}x^{2}=0.18 \\
p=0.337 \\
\text { IC } 95 \%=0.40 \\
-104.95\end{array}$ \\
\hline
\end{tabular}

